\title{
APPLICATIONS SUBSTITUTED 2-AMINOTHIOPHENES IN DRUG DESIGN
}

\author{
ZITA PUTEROVÁ ${ }^{1}$, ALŽBETA KRUTOŠÍKOVÁ ${ }^{2}$, DANIEL VÉGH ${ }^{3}$ \\ ${ }^{I}$ Department of Chemical Theory of Drugs, Faculty of Pharmacy, Comenius \\ University, Kalinčiakova 8, Bratislava, SK-832 3, Slovak Republic \\ (puterova@fpharm.uniba.sk) \\ ${ }^{2}$ Department of Chemistry, University of SS. Cyril and Methodius, J. Herdu 2, Trnava, \\ SK-917 01, Slovak Republic (alzbeta.krutosikova@ucm.sk) \\ ${ }^{3}$ Institute of Organic Chemistry, Catalysis and Petrochemistry, Faculty of Chemical \\ and Food Technology, Slovak University of Technology, Radlinského 9,Bratislava, \\ SK-812 37, Slovak Republic (daniel.vegh@stuba.sk)
}

\begin{abstract}
Highly substituted thiophene derivatives are important heterocycles found in numerous biologically active compounds. Title compounds are attractive derivatives because their applications in pharmaceuticals, agriculture and pesticides. They exhibit antimicrobial activity against various Gram $(+)$ and Gram(-) bacteria and fungi. Many of these molecules act as allosteric enhancers of $\mathrm{A}_{1}$-adenosine receptor, glucagon antagonists as well as antioxidant and anti-inflammatory agents.
\end{abstract}

Key words: Substituted 2-aminothiophenes, Gewald reaction, thieno[2,3- $d][1,3]$ oxazin-4-ones, allosteric enhancers, 3-deazathiadiamine, drug design

\section{Introduction}

The chemistry of 2-aminothiophenes has received much attention upon their convenient availability through the most versatile synthetic method developed by Gewald and his co-workers (GEWALD et al., 1988,). There are four basic variations originally described by Gewald and co-workers and about up to fifteen modifications to accomplish the synthesis of highly functionalized 2-aminothiophenes (SABNIS et al., 1999; GRONOWITZ and HÖRNFELDT, 2004). The improvements of the Gewald synthesis are based in diminution of the reaction time using microwave technology (HUANG et al., 2005, HESSE et al., 2007). The recent information of synthesis of title compounds is reviewed in our recent chapter (PUTEROVÁ and KRUTOŠÍKOVÁ, 2009). This article details about the use of substituted 2aminothiophenes in the synthesis of thieno- type heterocycles as a group of precursors applied in pharmaceuticals and in drug design.

\section{Synthesis of pharmaceuticals and drugs}

The ultimate positions of substituted 2-aminothiophenes in the field of drug design and synthesis of pharmaceuticals comes from their advantageous properties - the thiophene ring as is bioisosteric replacement for phenyl group broadly present in an active drugs, the thiophene core exists in many natural and synthetic pharmaceuticals. 
Moreover, they act as active precursors in broad range of synthetic pathways towards compounds used in therapy and biodiagnostic (JARVEST et al., 1999; DORÉ et al., 2004).

\subsection{5-Substituted 2-aminothiophenes as $A_{1}$ adenosine receptor allosteric enhancers}

Adenosine is an important endogenous tissue-protective compound released during ischemia, hypoxia or inflammation. Four receptor subtypes $\left(A_{1}, A_{2 A}, A_{2 B}, A_{3}\right)$ have been defined based on pharmacological properties (LINDEN, 1997). Considerable effort has been directed towards developing therapeutic agents targeting these receptors (BRUNS and FERGUS, 1990). Substituted 2-aminothiophenes of structure 1 - 4, with alkyl, aryl and cycloalkyl substituents in C-4 and C-5 position and aroyl substituent in C-3 position (Fig. 1), maintained the best allosteric enhancer activity (NIKOLAKOPOULOS et al., 2006; FERGUSSON et al., 2008).

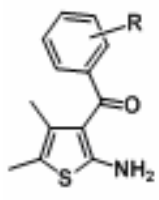

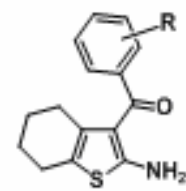

2

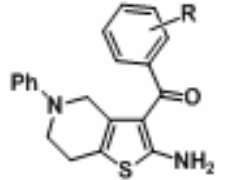

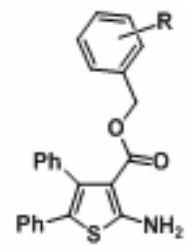

4

$\mathrm{R}=\mathrm{H}, 2-\mathrm{Cl}, 3-\mathrm{Cl}, 4-\mathrm{Cl}, 3,4-\mathrm{di}-\mathrm{Cl}, 3-\mathrm{CF}_{3}, 4-\mathrm{CF}_{3}, 4-\mathrm{CH}_{3}, 4-\mathrm{NO}_{2}, 4-\mathrm{CO}_{2} \mathrm{H}$, etc.

Fig. 1. Structure of some aminothiophene-based allosteric enhancers.

The significant effort in the area of synthetic aminothiophene-based allosteric enhancer is directed to development and synthesis of adenosine receptor agonists with limited side-effects. Since the active compounds with potential and utility are substituted 2-aminothiophenes their synthesis in principal based on the Gewald reaction.

\subsection{Synthesis thieno[2,3-d][1,3]oxazin-4-ones as inhibitors of Human Leukocyte Elastase}

A series of thieno[2,3- $d][1,3]$ oxazin-4-ones $8 \mathbf{a}-\mathbf{h}$ was synthesized and evaluated in vitro for inhibitory activity toward Human Leukocyte Elastaze (HLE). The strategy presented by authors (GÜTSCHOW and NEUMAN, 1998; GÜTSCHOW et al., 1999) is base on the replacement of the benzene ring in benzoxazinones by thiophene. The study demonstrates the versatility of 2-aminothiophenes prepared by Gewald reaction as a synthetic entry to serine protease-inhibiting, fused 1,3-oxazin-4-ones. The synthetic route to novel thieno[2,3- $d][1,3]$ oxazin-4-ones 8a - h using alkyl 2aminothiophenecarboxylates $\mathbf{5 a , b}$ as substrates exhibits a facile three step synthesis, as is presented on Scheme 21. Aminothiophenes 5a,b were converted to isothiocyanato- 
thiophenes $\mathbf{6 a}, \mathbf{b}$ by the action of thiophosgene. Deprotection of tert-butoxycarbonyl group resulted directly to ring closure of the intermediates isothiocyanatothiophenecarboxylic acids 7a,b. These key intermediates were alkylated with appropriate alkyl halides to furnish the final derivatives $\mathbf{8 a}-\mathbf{h}$ (Scheme 1).

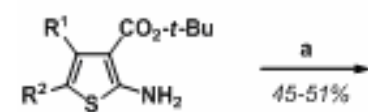

$$
\text { 5a: } \mathrm{R}^{1}=\mathrm{R}^{2}=-\left(\mathrm{CH}_{2}\right)_{4}
$$$$
\text { 5b: } R^{1}=R^{2}=M e
$$

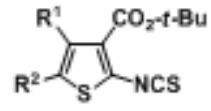

$$
\text { 6a: } R^{1}=R^{2}=\left\langle\mathrm{CH}_{2}\right\rangle^{-}
$$$$
\text { 6b: } R^{1}=R^{2}=M e
$$
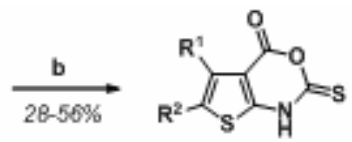

7a: $R^{1}=R^{2}=-\left(\mathrm{CH}_{2}\right) \cdot$ 7b: $\mathrm{R}^{1}=\mathrm{R}^{2}=\mathrm{Me}$

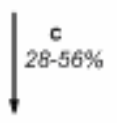

8a: $R=M e, R^{1}=R^{2}=\left\langle C_{2}\right\rangle$

8b. $R=M e R^{1}=R^{2}=M e$

8c: $R=E t, R^{1}=R^{2}=-\left(\mathrm{CH}_{2}\right)_{4}$.

8d: $R=E t, R^{1}=R^{2}=M e$

8e: $\mathrm{R}=\mathrm{CH}_{2} \mathrm{Ph}, \mathrm{R}^{1}=\mathrm{R}^{2}=-\left(\mathrm{CH}_{2} \mathrm{~h}_{4}\right.$

8f: $\mathrm{R}=\mathrm{CH}_{2} \mathrm{Ph}, \mathrm{R}^{1}=\mathrm{R}^{2}=\mathrm{Me}_{\mathrm{e}}$

$8 \mathrm{~g}: \mathrm{R}=\mathrm{CH}_{2} \mathrm{CO}_{2} \mathrm{Me}, \mathrm{R}^{1}=\mathrm{R}^{2}=\left\langle\mathrm{CH}_{2}\right\}_{4}$

$8 \mathrm{~h}: \mathrm{R}=\mathrm{CH}_{2} \mathrm{CO}_{2} \mathrm{Me}, \mathrm{R}^{1}=\mathrm{R}^{2}=\mathrm{Me}$

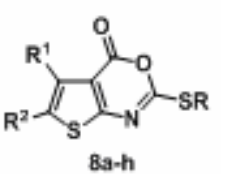

8a-h

a: $\mathrm{CSCl}_{2}, \mathrm{CaCO}_{3}, \mathrm{CH}_{2} \mathrm{Cl}_{2}, \mathrm{H}_{2} \mathrm{O}, 0^{\circ} \mathrm{C}$; b: TFA, $\mathrm{CH}_{2} \mathrm{Cl}_{2}, 0^{\circ} \mathrm{C}$; c: Mel or RBr, $\mathrm{Na}_{2} \mathrm{CO}_{3}$ acetone, RT

Scheme 1. Synthesis of substituted thieno[2,3- $d][1,3]$ oxazin-4-ones $\mathbf{8 a}-\mathbf{h}$

Extracellurar HLE is a serine protease contained in the azurophilic granules of human neutrophils and has been shown to contribute to the pathogenesis of destructive lung diseases, such as pulmonary emphysema, cystic fibrosis, adult respiratory distress syndrome and inflammatory disorders such as rheumatoid arthritis. For that reason, much attention is focused on the inhibition of HLE by low-molecular-weight inhibitors that might serve as therapeutic agents.

\subsection{Synthesis of 3-deazathiamine}

Authors (HAWSKEY et al., 2001) outlined the synthesis of 3-deazathiamine (13) in ten chemical steps, through key intermediate substituted 2-aminothiophene $\mathbf{9}$. On the Scheme 2 we have outlined the synthesis of target compound $\mathbf{1 3}$ starting from appropriate aminothiophene $\mathbf{9}$. Deamination of aminothiophene $\mathbf{9}$ via the bromide and following cleavage with $\mathrm{Zn}$ in acid media to afford derivative $\mathbf{1 0}$ was very efficient, displaying none of side reactions. Conversion of formed ester $\mathbf{1 0}$ to final 3deazathiamine (12) was accomplished in four subsequent steps isolating the crucial intermediates - aldehyde $\mathbf{1 1}$ and nitrile 12. The readily available and inexpensive starting materials and reagents, and the lack of protection and de-protection steps make this synthesis very fashionable (Scheme 2).

Deazathiamine diphosphate (deaza-TDP) is an analogue of thiamine diphosphate (TDP), the biologically active for of thiamin (vitamin $\mathrm{B}_{1}$ ), with a neutral thiophene replacing positively charged thiazolium ring. TDP is co-enzyme present in a number of enzymes, including pyruvate decarboxylase, transketolase, pyruvate oxidase. 

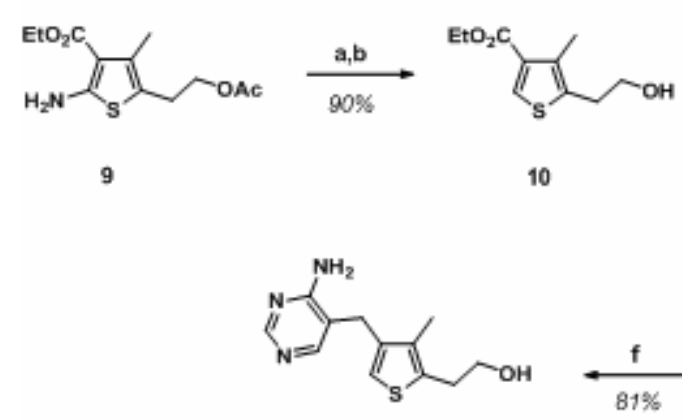

13

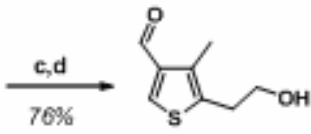

11

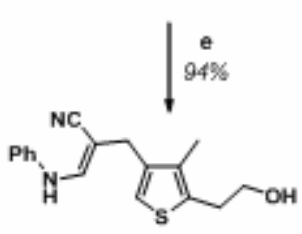

12

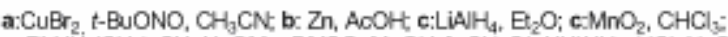

e: $\mathrm{PhNH}-\left(\mathrm{CH}_{2}\right)_{2} \mathrm{CN}, \mathrm{NaOMe}$, DMSO, $\mathrm{MeOH} ; \mathrm{j}: \mathrm{CH}_{3} \mathrm{C}(=\mathrm{NH}) \mathrm{NH}_{2}, \mathrm{HCl}, \mathrm{NaOEt}, \mathrm{ENOH}$.

Scheme 2. Reaction sequence towards 3-deazathiamine 13.

\subsection{Other important pharmaceuticals developed from2-aminothiophenes}

The synthesis and antitumor a potent thieno[2,3- $b$ ]azepin-4-one antineoplastic agents was reported (KOEBEL et al., 1975). The meaningful structure-activity relationships have been established in monocarbonyl and dicarbonyl series of thieno[2, 3-b]azepin-4-one 14, 15 (Fig. 2) prepared by Dieckmann ring closure reaction in multi step reaction from substituted 2-aminothiophenes.

Cinnamyl derivatives of thieno[2, 3- $d$ ] oxazinones 16 (Fig. 3) inhibits herpes protease processing in HSV-2 infected cells. The synthesis and pharmacology of this series of derivatives was presented by authors (JARVEST et al., 1997 and 1999) from ethyl 2amino-4-methylthiophene-3-carboxylate.

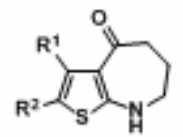

14

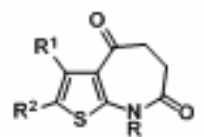

15

$R^{1}=R^{2}=M e, R^{1}=P h, R^{2}=M e, R=$ tosyl of benzoyl

Fig. 2. Structure of potential antineoplastics Thieno (2,3-b) azepin-4-ones 14,15

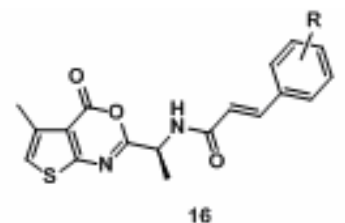

$\mathrm{R}=\mathrm{H}, 2-\mathrm{Cl}, 2-\mathrm{Br}, 2-\mathrm{Me}_{0}, 2-\mathrm{NO}_{2}, 2-\mathrm{E} 1 \mathrm{O}, 4-\mathrm{CHO}$

Fig. 3. The family of herpes proteases HSV-2 Thieno (2,3-d) oxazinones 16 
Transglutaminases (TGases) are a family of $\mathrm{Ca}^{2+}$ dependent enzymes which are normally expressed at low levels in many different tissues and serve vital roles, such as blood clothing and epithelia formation. Some TGase isoenzymes are involved in diverse pathological conditions like celiac disease, atherosclerosis and neurodegenerative disorders. Thieno[2,3- $d$ ]pyrimidin-4-hydrazide derivatives related to structure 17 (Fig. 4) were discovered as a moderately potent inhibitors of TGase-2 (tissue transglutaminase) (DUVAL et al., 2000).

The RNA polymerase holoenzyme is a proven target for antibacterial agents. A high-throughput screening program based on this enzyme from Staphylococcus aureus had identified a 2-ureido-thiophene-3-carboxylate 18 (Fig. 5) as a low micromolar inhibitor. It displayed good antibacterial activity against $S$. aureus and $S$. epidermidis. Based on these observations the authors (AHRIN et al., 2006) reported a facile synthesis of the number of analogs of $\mathbf{1 8}$ via the Gewald reaction and evaluated for cytotoxic activity against Rifampicin-resistant $S$. aureus.

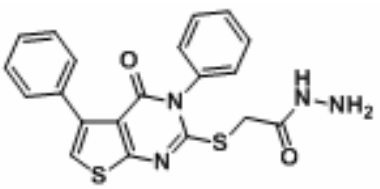

17

Fig. 4. Thieno (2,3- $d$ ) pyrimidin-4-hydrazide 17 lead structure in inhibition of TGase-2.

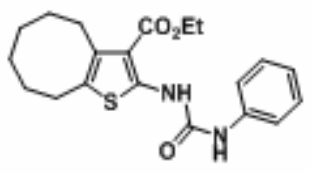

18

Fig. 5. 2-Ureido-thiophene-3-carboxylate 18 antibacterial agent against $S$. aureus.

A novel class of thiophene-derived antagonists of the human hepatic glucagon receptor (hGCRG) has been discovered (DUFFY et al., 2005). The synthesis of derivatives based on the lead structure 19 (Fig. 6) was accomplished using the Gewald reaction. The further investigations of such structures are challenging in development of therapeutics of the diabetes mellitus. Diabetes mellitus is a condition characterized by chronically elevated levels of blood glucose caused by incorrect function of the hormone responsible for the hGCRG activation.

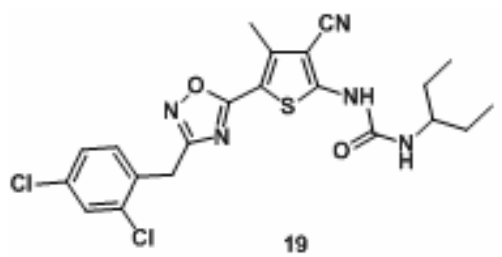

Fig. 6. Thiophene-based antagonist of hGCRG 19 
Because the structure-based drug design program through substituted 2aminothiophenes has been investigated broadly, up to this date there are many other research works dealing with the synthesis, pharmacology and application of thiophenebased structures in medicinal chemistry (KOUROUNAKIS et al., 2000). It is no doubt, that this area of Gewald-like thiophene derivatives exhibits the highest progress in a scope and utilization.

\section{Conclusions}

In this short review the importance of substituted 2-aminothiophenes in the medicinal chemistry was extended in terms of drug design and synthesis of pharmaceuticals. The scope of this work does not include all of the publications in this field, but the most interesting studies in the subject areas are considered. The further detailed information in the latter aspects can be found within the list of the references.

Acknowledgements: The support of this work by grants VEGA 1/1005/09, VEGA $1 / 4453 / 07$, VEGA $1 / 4300 / 07$, VVCE $0004-07$ and UK/102/2009 is gratefully acknowledged

\section{References}

ARHIN, F., BÉLANGER, O., CIBLAT, S., DEHBI, M., DELORME, D., DIETRICH, E., DIXIT, D., LAFONTAINE, Y., LEHOUX, D., LIU, J., McKAY, G. A., MOECK, G., REDDY, R., ROSE, Y., SRIKUMAR, R., TANAKA, K.S.E., WILLIAMS, D.M., GROS, P., PELLETIER, J., PARR, T.R., RAFAI FAR, A.: Triaminotriazine DNA helicase inhibitors with antibacterial activity. Bioor. Med. Chem. Lett., 16, 2006, 1286-1290.

BRUNS, R.F., FERGUS, J.H.: Allosteric enhancement of adenosine $\mathrm{A}_{1}$ receptor binding and function by 2-amino-3-benzoylthiophenes. Mol. Pharmacol., 38, 1990, 939-949.

DORÉ, K., DUBUS, S., HO, H.-A., LÉVESQUE, I., BRUNETTE, M., CORBEIL, G., BOISSINOT, M., BOIVIN, G., BERGERON, M., BOUDREAU, D., LECLERC, M.: Fluorescent Polymeric Transducers for the rapid, simple and specific detection of Nucleic acids at the zeptomole level. J. Am. Chem. Soc., 126, 2004, 263-287.

DUFFY, J.L., KIRK, B.A., KONTEATIS, Z., CAMPBELL, E.L., LIANG, R., BRADY, E. J., CANDELORE, M.R., DING, V.D.H., JIANG, G., LIU, F., QURESHI, S.A., SAPERSTEIN, R., SZALKOWSKI, D., TONG, S., TOTA, L.M. XIE, D., YANG, X., ZAFIAN, P., ZHENG, S., CHAPMAN, K.T., ZHANG, B.B., TATA, J.R.: Discovery and investigation of a novel class of thiophene-derived antagonists of the human glucagon receptor. Bioor. Med. Chem. Lett., 15, 2005, 1401-1405.

DUVAL, E., CASE, A., STEIN, R., CUNY, G.D.: Structure-activity relationship study of novel tissue transglutaminaze inhibitors. Bioor. Med. Chem. Lett., 15, 2005, 1885-1889.

FERGUSSON, G.N., VALANT, C., HORNE, J., FIGLER, M., FLYNN, B.L., LINDEN, J., CHALMERS, D.K., SEXTON, P.M., CHRISTOPOULOS, A., 
SCAMMELLS, P.: 2-Aminothienopyridazines as novel adenosine $\mathrm{A}_{1}$ receptor allosteric modulators and antagonists. J. Med. Chem., 51, 2008, 6165-6172.

HAWSKEY, D., GRIFFIN, D.A., LEEPER, F.J.: Synthesis of 3-deazathiamine. J. Chem. Soc. Perkin Trans., 1, 2001, 144-148.

HESSE, S., PERSPICACE, E., KIRSCH, G.: Microwave assisted synthesis of 2aminothiophene-3-carboxylic acid derivatives, 3H-thieno[2,3- $d]$ pyrimidin-4-one and 4-chlorothieno[2,3- $d$ ]pyrimidine. Tetrahedron Lett., 48, 2007, 5261-5264.

HUANG, W. LI, J., TANG, J., LIU, H., SHEN, J.; JIANG, H.: Microwave assisted synthesis of 2-amino-thiophene-3-carboxylic acid derivatives under solvent-free conditions. Synthetic Comm., 35, 2005, 1351-1357.

GEWALD, K., GRUNER, M., HAIN, U., SÜPTITZ, G.: Ringtransformation of ethyl2-aminothiophene-3-carboxylates: Derivatives of pyridones and pyridazinones. Monatsh. Chem., 119, 1988, 985-992.

GRONOVITZ, S., HÖRNFELDT, A.B.: Thiophenes (Best Synthetic Methods). KATRITZKY, A., METH-COHN, O., REES, C. V. (Eds.), Elsevier Academic Press, Kidlington, Oxford, UK, 2004, 1-986.

GÜTSCHOW, M., KUERSCHNER, L., NEUMANN, U., PIETSCH, M., LÖSER, R., KOGLIN, N., EGER, K.: 2-(Diethylamino)thieno[1,3]oxazin-4-ones as stable inhibitors of human leukocyte elastaze. J. Med. Chem., 42, 1999, 5437-5447.

GÜTSCHOW, M., NEUMANN, U.: Novel thieno[2,3- $d][1,3]$ oxazin-4-ones as inhibitors of human leukocyte elastaze. J. Med. Chem., 41, 1998, 1729-1740.

JARVEST, R.L., CONNOR, S.C., GORNIAK, J.G., JENNINGS, L.J., SERAFINOVSKA, H.T., WEST, A.: Potent selective thienoxazinone inhibitors of herpes proteases. Bioor. Med. Chem. Lett., 7, 1997, 1733-1738.

JARVEST, R.L., PINTO, I.L., ASHMAN, S.M., DABROWSKI, C.E., FERNANDEZ, A.V., JENNINGS, L.J., LAVERY, P., TAW, D.G.: Inhibition of herpes proteases and antiviral activity of 2-substituted thieno[2,3- $d$ ] oxazinones. Bioor. Med. Chem. Lett., 9, 1999, 443- 448.

KOEBEL, R.F., NEEDHAM, L.L., De WITT BLANTON, C.: Synthesis of thieno[2,3b]azepines-4-ones. J. Med. Chem.,18, 1975, 192-194.

KOUROUNAKIS, A.P., VAN DER KLEIN, P.A. M., IJZERMAN, A.P.: Allosteric modulations of the rat adenosine $A_{1}$ receptor: Differential effects on agonist and antagonist binding. Drug Dev. Res. 49, 2000, 227-237.

LINDEN, J.: Allosteric enhacement of adenosine receptor. In: K.A. JACOBSON, M.F. JARVIS (Eds.) Purinergic Approaches in Experimental Therapeutics. WileyLiss, New York, US, 1997, 85-97.

NIKOLKOPOULOS, G., FIGLER, H., LINDEN, J., SCAMMELLS, P.: 2-Aminothiophene-3-carboxylates and carboxamides as adenosine $\mathrm{A}_{1}$ allosteric enhancers. Bioorg. Med. Chem., 14, 2006, 2358-2365.

PUTEROVÁ, Z., KRUTOŠÍKOVÁ, A.: Substituted 2-aminothiophenes: Synthesis, Properties and Applications. In: K. NYLUND, P. JOHANSON (Eds.) Heterocyclic Compounds: Synthesis, Properties and Applications. Novascience, New York, 2009 (in press).

SABNIS, R.W., RANGNEKAR, D.W., SONAWANE, N.D.: 2-Aminothiophenes by the Gewald reaction. J. Heterocycl. Chem., 36, 1999, 333-345. 